\title{
Renal cell tumors convert natural killer cells to a proangiogenic phenotype
}

\author{
Yue Guan ${ }^{1}$, Christopher B. Chambers ${ }^{1}$, Taylor Tabatabai ${ }^{1}$, Ha Hatley ${ }^{1}$, Kristin R. \\ Delfino $^{3}$, Kathy Robinson ${ }^{4,5}$, Shaheen R. Alanee ${ }^{2,5}$, Sophia Ran ${ }^{1,5}$, Donald S. Torry ${ }^{1,5}$ \\ and Andrew Wilber ${ }^{1,5}$ \\ ${ }^{1}$ Department of Medical Microbiology, Immunology and Cell Biology, Southern Illinois University School of Medicine, \\ Springfield, IL 62702, USA \\ ${ }^{2}$ Department of Surgery, Division of Urology, Southern Illinois University School of Medicine, Springfield, IL 62702, USA \\ ${ }^{3}$ Center for Clinical Research, Southern Illinois University School of Medicine, Springfield, IL 62702, USA \\ ${ }^{4}$ Department of Internal Medicine, Southern Illinois University School of Medicine, Springfield, IL 62702, USA \\ ${ }^{5}$ Simmons Cancer Institute, Springfield, IL 62702, USA
}

Correspondence to: Andrew Wilber, email: awilber@siumed.edu

Keywords: kidney cancer; innate immunity; natural killer cells; immunosuppression; angiogenesis

Received: March 27, $2020 \quad$ Accepted: June 05, $2020 \quad$ Published: June 30, 2020

Copyright: Guan et al. This is an open-access article distributed under the terms of the Creative Commons Attribution License 3.0 (CC BY 3.0), which permits unrestricted use, distribution, and reproduction in any medium, provided the original author and source are credited.

\section{ABSTRACT}

Natural killer (NK) cells are classically associated with immune surveillance and destruction of tumor cells. Inconsistent with this function, NK cells are found in advanced human tumors including renal cell carcinoma (RCC). NK cells with nonclassical phenotypes (CD56+CD16 dim/neg; termed decidua NK (dNK) cells) accumulate at the maternal-fetal interface during embryo implantation. These dNK cells are poorly cytotoxic, proangiogenic, and facilitate placenta development. As similarities between embryo implantation and tumor growth exist, we tested the hypothesis that an analogous shift in NK cell phenotype and function occurs in RCC tumors. Our results show that peripheral NK (PNK) cells of RCC patients were uniformly CD56 ${ }^{+}$CD 16 ${ }^{\text {bright, }}$ but lacked full cytotoxic ability. By comparison, RCC tumor-infiltrated NK (TiNK) cells were significantly enriched for $\mathrm{CD56}{ }^{+} \mathrm{CD} 16^{\text {dim-neg }}$ cells, a phenotype of dNK cells. Gene expression analysis revealed that angiogenic and inflammatory genes were significantly increased for RCC TiNK versus RCC pNK populations, with enrichment of genes in the hypoxia inducible factor (HIF) 1a pathway. Consistent with this finding, NK cells cultured under hypoxia demonstrated limited cytotoxicity capacity, but augmented production of vascular endothelial growth factor (VEGF). Finally, comparison of gene expression data for RCC TiNK and dNK cells revealed a shared transcriptional signature of genes with known roles in angiogenesis and immunosuppression. These studies confirm conversion of pNK cells to a dNKlike phenotype in RCC tumors. These characteristics are conceivably beneficial for placentation, but likely exploited to support early tumor growth and promote metastasis.

\section{INTRODUCTION}

In humans, natural killer (NK) cells make up $5-20 \%$ of the nucleated cells in the peripheral blood, and are identified as $\mathrm{CD}^{\text {neg }}$ lymphocytes that express CD56 with or without CD16. These two subtypes of NK cells demonstrate distinct differences in phenotype and function. Most (90-95\%) peripheral blood NK (pNK) cells are $\mathrm{CD} 56^{+} \mathrm{CD} 16^{\text {bright }}$ and exhibit efficient cytotoxic responses. A small percentage $(5-10 \%)$ of pNK cells are $\mathrm{CD} 56^{+} \mathrm{CD} 16^{\text {dim/neg }}$ with little cytotoxic function and enhanced proinflammatory cytokine production, including gamma interferon (IFN $\gamma$ ), tumor necrosis factor alpha $(\mathrm{TNF} \alpha)$, and granulocyte macrophage-colony stimulating 
factor (GM-CSF) [1]. Tumor-infiltrated NK (TiNK) cells have impaired tumor cytotoxicity and increased proinflammatory cytokine production [2, 3]. However, less is known regarding the proangiogenic properties of TiNK cells or the mechanisms driving functional conversion [4].

The predominant lymphocyte population in the decidua during early placentation is NK cells. These decidua NK (dNK) cells comprise $75 \%$ of lymphocytes at the implantation site are phenotypically $\mathrm{CD} 56^{+} \mathrm{CD} 16^{\text {neg }}$ and demonstrate limited to no cytotoxicity capacity [5-8]. Human dNK cells secrete angiogenic molecules, particularly placenta growth factor (PGF) and vascular endothelial growth factor A (VEGFA) [5], angiopoietins (ANG), and transforming growth factor-beta (TGF $\beta$ ) [6]. Accumulation of dNK cells correlates with the formation of blood and lymphatic vessels, endometrial edema and vasodilation leading to increased uterine artery blood flow $[7,8]$. Thus, $\mathrm{CD} 56^{+} \mathrm{CD} 16^{\text {neg }} \mathrm{NK}$ cells could have significant, yet under-appreciated, roles in promoting angiogenesis in a number of pathological situations, including tumor growth and metastasis.

Renal cell carcinoma (RCC) is a major health issue with $\sim 25 \%$ mortality rate at diagnosis. This is attributed to $40 \%$ of patients presenting with or developing metastatic disease and suboptimal efficacy of available treatments such as chemotherapy and radiation $[9,10]$. Survival improves following surgery combined with cytokine therapy, but response rates have not exceeded $20 \%$ [11]. Suppression of tumor immunity by RCC likely imposes functional limitations on the effectiveness of immunotherapy [12]. Infiltration of NK cells at RCC sites is observed and these TiNK cells have limited cytotoxic potential and express differential repertoires of activating and inhibitory receptors [13-15]. The proangiogenic roles of NK cells in RCC and other tissue-specific cancers have not been investigated, and little has been reported about mechanisms responsible for the functional conversion of NK cells in the tumor environment.

Given the fundamental role of NK cells in tumor immunity, identifying the mechanisms by which tumors alter NK cell function may prove critical for controlling tumor growth. We investigated the extent to which RCC tumors could alter the phenotype and function of NK cells in the peripheral blood and tumor tissue of newlydiagnosed patients. We found that NK cells isolated from human RCC tumors are phenotypically different from matched pNK cells. Molecular characterization of RCC TiNK versus pNK revealed up-regulation of angiogenic and inflammatory genes, many of which were enriched in the hypoxia inducible factor (HIF) $1 \alpha$ pathway. In line with this finding, NK cells cultured under hypoxia demonstrated increased production of the angiogenic molecule VEGFA and reduced cytotoxic potential. Finally, comparison of upregulated genes to results from a published microarray for bona fide dNK cells [5] identified a shared genetic signature consisting of genes with known roles in vascularization and immunosuppression. These collective findings confirm that RCC tumors are able to alter the classical characteristics of NK cells towards a dNK-like program. While these characteristics are beneficial for placentation, they may be exploited to support RCC growth and metastasis.

\section{RESULTS}

\section{Peripheral blood NK cells of RCC patients have reduced cytotoxic activity}

A role for tumor immunity in controlling RCC has been implicated following rare clinical observations of spontaneous disease regression. The majority of these cases involved regression of metastases after removal of the primary tumor $[16,17]$. Puzzling, however, were findings that high levels of tumor infiltrating lymphocytes (TIL), including NK cells, are common to RCC [1315]. We hypothesized that NK cells of RCC patients were phenotypically and functionally altered within the circulation and/or tumor environment resulting in impaired tumor immunity. To explore the phenotype and function of NK cells in patients with RCC, we enrolled six patients newly diagnosed with this cancer. All patients were males between the age of 50 and 70 years old and none had received prior treatment for the disease. The clinical characteristics of these patients are shown in Table 1. NK cells were isolated from peripheral blood mononuclear cells (PBMC) by negative selection using a cocktail of antibody-magnetic microbeads. Multi-color flow cytometry was used to identify NK cells $\left(\mathrm{CD}^{2} 5^{+} /\right.$ $\mathrm{CD} 3 / \mathrm{CD}^{2} 6^{+}$cell population) and gauge expression of CD16. Like pNK cells of healthy, cancer-free donors, the $\mathrm{CD} 56^{+} \mathrm{CD} 16^{+} \mathrm{NK}$ subset was predominant for RCC patients (Figure 1A). We did not observe a significant difference in the mean percentage of $\mathrm{CD} 56^{+} \mathrm{CD} 16^{+} \mathrm{NK}$ cells between healthy donors and RCC patients, but there was variation in proportion of $\mathrm{CD} 56^{+} \mathrm{CD} 16^{+}$cells among RCC patients. Cytotoxic activity of freshly-isolated pNK cells of RCC patients was, however, significantly reduced compared to healthy controls at all tested target:effector ratios (Figure 1B). As TGF $\beta$ treatment has been reported to reduce cytotoxic ability of NK cells [18], we measured the amount of TGF $\beta$ in the plasma of RCC patients by ELISA. Compared to healthy volunteers, TGF $\beta$ levels were 3-fold higher for RCC patients (Figure 1C). These findings suggest that production of TGF $\beta$ by RCC tumors impacts the function of $\mathrm{pNK}$ cells in the circulation.

\section{Human RCC tumor-derived NK cells acquire altered phenotype and gene expression}

To identify alterations that were RCC tumorinduced, we compared NK cells isolated from RCC tumors (TiNK) to matched pNK cells for the six patients. 
The proportion of TiNK cells averaged 18\% (range $1.8 \%$ to $36.8 \%$ ) of the total $\mathrm{CD} 45^{+}$population (Table 1 ), which is consistent with previous reports of RCC tumors being infiltrated by lymphocytes, including NK cells [13-15]. Flow cytometry analysis of NK cells isolated from peripheral blood (Figure $2 \mathrm{~A}$ ) or RCC tumor tissue (Figure $2 \mathrm{~B}$ ) revealed that the $\mathrm{CD} 56^{+} \mathrm{CD} 16^{\mathrm{dim} / \mathrm{neg}^{-}}$population was significantly enriched for RCC tumors, with mean levels nearly 8-times higher (pNK 6.3\% vs. TiNK 47.5\%), although variation was noted for individual patients (Figure 2C).

To explore molecular signatures that characterized TiNK cells, we used total RNA isolated from purified pNK and TiNK cells of four patients to perform a focused RTqPCR array consisting of 79 genes with known association to angiogenesis and inflammation. The percentage of the $\mathrm{CD}^{+} 6^{+} \mathrm{CD} 16^{\mathrm{dim} / \mathrm{neg}}$ population for $\mathrm{NK}$ cells isolated from peripheral blood or RCC tumor tissue of these four
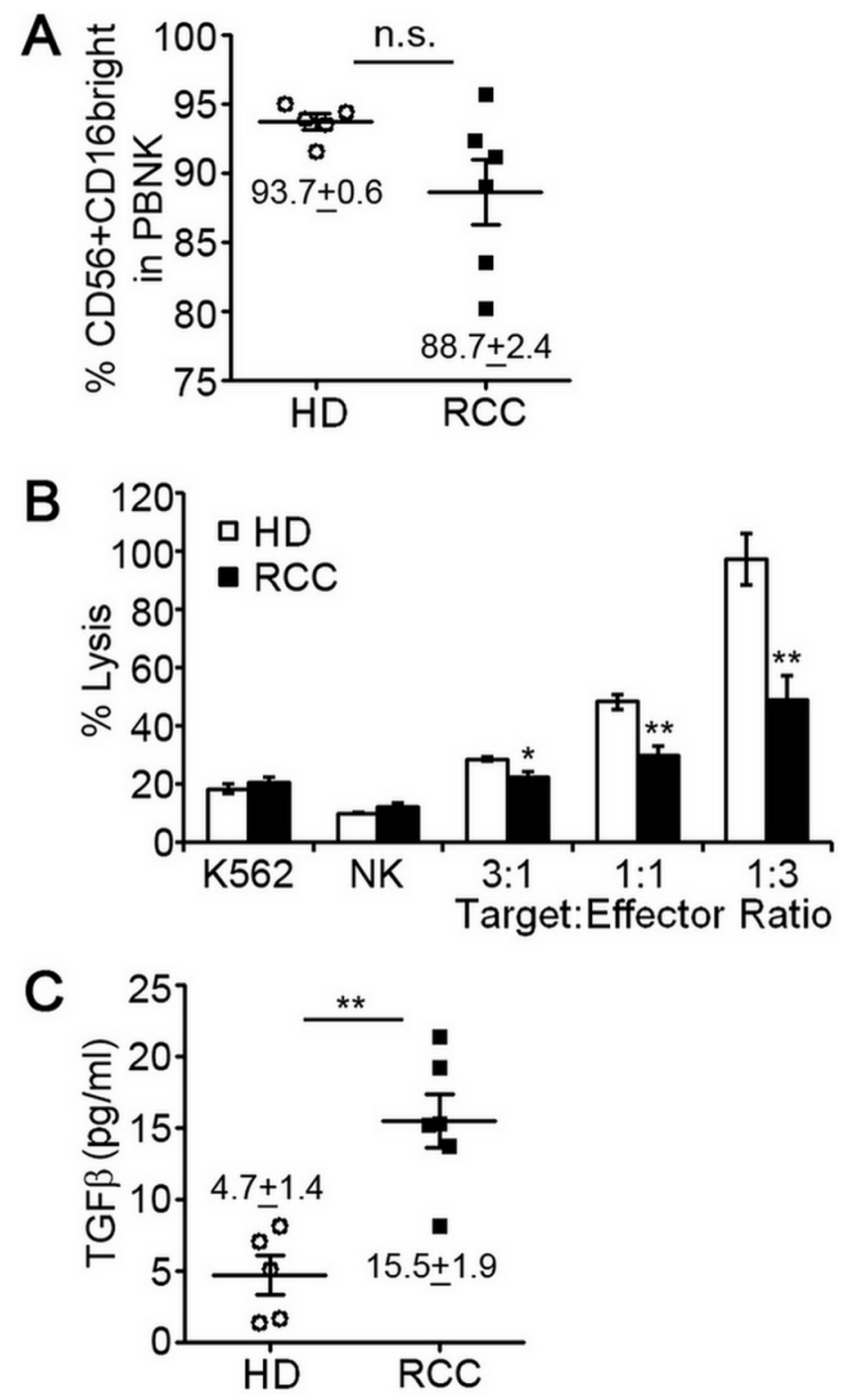

Figure 1: Peripheral blood NK cells of RCC patients have decreased cytotoxic function. NK cells were isolated from peripheral blood of 5 healthy, cancer-free donors (HD) or 6 patients diagnosed with RCC by negative selection and evaluated for expression of surface markers by multi-color flow cytometry or ability to lyse K562 human erythroleukemia cells. (A) Percentage of CD56 ${ }^{+}$CD16 ${ }^{+}$ pNK cells isolated from HD or RCC patients with mean \pm SEM reported. Each symbol represents an independent person. (B) Relative cytotoxic activity of freshly isolated pNK cells from HD or RCC patients for the indicated target:effector ratios. Data are analyzed relative to K562 cells treated with digitonin serving as a positive control for cell death (set $=100 \%$ lysis) and plotted as mean \pm SEM ( $n=5$ healthy donors and RCC patients). (C) Concentrations of activated TGF $\beta$ in plasma from healthy donors and RCC patients determined by ELISA with mean \pm SEM reported. Each symbol represents an independent person. n.s., not significant; ${ }^{*} P \leq 0.05 ;{ }^{* *} P \leq 0.01$; determined by Student's $t$-test. 
Table 1: Characteristics of patients with resected RCC tumors analyzed

\begin{tabular}{|c|c|c|c|c|c|c|c|}
\hline No. & Age & Histology & Stage & Tumor Sample (g) & Total Yield $\left(\times 10^{6}\right)^{+}$ & CD45+ $(\%)^{\#}$ & $\mathrm{CD56}+(\%)^{\wedge}$ \\
\hline 1 & 70 & Clear Cell & III & 1.3 & 30 & 74.4 & 4.1 \\
\hline 2 & 55 & Clear Cell & III & 2.6 & 10 & 89.9 & 36.8 \\
\hline 3 & 67 & Clear Cell & III-IV & 3.6 & 20 & 99.0 & 23.9 \\
\hline 4 & 50 & Clear Cell & III-IV & 1.1 & 1.7 & 99.6 & 1.8 \\
\hline 5 & 59 & Clear Cell & IV & 3.0 & 20 & 82.8 & 34.9 \\
\hline 6 & 66 & Clear Cell & I-II & 0.8 & 1.7 & 97.4 & 6.0 \\
\hline
\end{tabular}

tTotal number of cells recovered following centrifugation of dissociated tumor tissue through $35 \%$ Percoll gradient. "\#Percentage of recovered cells that were CD45 positive by flow cytometry. ${ }^{\wedge}$ Percentage of CD45 positive cells that co expressed CD56 when analyzed by flow cytometry.

patients are reported in Supplementary Table 1. RNA samples were analyzed in triplicate and expression level calculated as percentage of $\beta$-actin because transcript levels for this gene were essentially unchanged for pNK and TiNK populations ( $p=0.92$ by $t$-test). Supplementary Table 2 shows the results for all 79 genes as mean foldchange \pm SEM and ordered from greatest to least foldchange. As defined by $(P \leq 0.05$ and mean fold-change $\geq 5$ ), 42 out of 79 tested genes were upregulated for TiNK versus pNK populations. Figure 3 shows a heat map depicting differential expression of selected upregulated genes for $\mathrm{pNK}$ versus TiNK cells based on calculated Z-scores. KEGG pathway analysis showed that upregulated genes were enriched in pathways related with HIF1, TNF, NFKB, and transcriptional misregulation in cancer with HIF1 signaling demonstrating the greatest significance (Table 2). In line with this finding, mRNA levels of proangiogenic VEGF were significantly elevated for TiNK versus $\mathrm{pNK}$ cell populations from these patients (Supplementary Table 1). Thus, RCC tumor-infiltrating NK cells have pronounced phenotypic and functional alterations compared with matched pNK cells; effects that are likely influenced by the tumor microenvironment.

\section{Hypoxia conversion of $\mathrm{pNK}$ cells to dNK-like cells}

Advanced tumors have abnormal vasculature and insufficient oxygen supply making hypoxia a common feature of the tumor environment [19]. Hypoxia contributes to malignant progression in cancer by inducing an invasive and metastatic phenotype and by activating resistance mechanisms to create an immunosuppressive environment [20]. To test the extent to which hypoxia could enhance the proangiogenic phenotype of pNK cells, we cultured pNK cells ( $n=5$ healthy donors) for four days under normal oxygen $\left(21 \% \mathrm{O}_{2}\right)$ or hypoxia $(1 \%$ $\mathrm{O}_{2}$ ), and assayed for proangiogenic VEGFA expression and cytotoxic potential. Because hypoxia can influence cell survival, trypan blue exclusion assay was used to confirm comparable numbers of viable cells under these growth conditions. Thus, changes in gene expression and cytotoxic ability were unrelated to differences cell viability. VEGFA mRNA and protein were expressed at low levels for NK cells cultured under normoxic conditions. Hypoxia clearly affected NK cells as evidenced by well-known upregulation of VEGFA mRNA with mean levels increased 11-fold when quantified by RT-qPCR (Figure 4A). ELISA of conditioned culture supernatants confirmed enhanced production of VEGFA under hypoxic growth conditions $\left(51 \mathrm{pg} / \mathrm{mL} 21 \% \mathrm{O}_{2}\right.$ vs. $143 \mathrm{pg} / \mathrm{mL} 1 \% \mathrm{O}_{2}$; Figure 4B). Concomitantly, we observed decreased cytotoxicity (Figure 4C), which may result from VEGFA upregulation and/or other HIF1 $\alpha$ regulated factors (Supplementary Figure 1) [21-23]. Thus, conversion of pNK cells to a dNK-like phenotype (poor cytotoxic potential and elaboration of VEGFA expression) is favored by hypoxia; a factor with key roles in tumor invasion and metastasis and response to therapy $[19,20]$.

\section{RCC tumor NK cells and decidua NK cells have a shared transcriptional profile}

Decidua NK cells undergo tissue-specific alterations, which impart their unique ability to regulate vascular remodeling, an essential step for placental growth [24, 25]. Previously, Hanna and colleagues performed a microarray analysis on purified dNK cells to obtain a transcriptional profile of cytokines, chemokines and growth factors using CodeLinkTM Uniset Human 20K I Bioarray, which provides coverage for about 20,000 human genes [5]. To gain additional insight into the function of RCC TiNK cells, we compared gene expression results for our 79 genes to these microarray data (Supplementary Table 3). We first looked at genes with any increase above the minimum hybridization threshold of 20 for dNK cells versus genes increased by 2-, 4-, 8-, or 16-fold for TiNK cells. This analysis revealed that as the level of gene expression increased for TiNK cells it became more likely that these same genes were upregulated in dNK cells $\left(R^{2}=0.98\right)$ (Figure 5A). Comparison of genes induced by at least 2 -fold for dNK cells and at least 4-fold for TiNK cells identified 1,158 genes for dNK cells and 46 for TiNK cells with 9 genes present in both data sets 
(Figure 5B). Genes with any increase above the minimum threshold of 20 for dNK cells were also plotted against matched counterparts for TiNK cells (Figure 5C). This comparison identified genes that were relatively nonspecific, specific to dNK or TiNK, or shared by both dNK and TiNK. It is important to note that CD146 was significantly increased for dNK cells (53.8-fold increase over the minimum threshold), but assigned a value of 8 for visualization purposes in the graphical representation. For the 9 shared genes, the majority have known roles in angiogenesis, immune modulation, tumor development, and/or metastasis (Table 3). As angiogenesis and immune modulation are critical features of tumor and decidua environments, these gene expression results provide further evidence for similarities between $\mathrm{dNK}$ and RCC TiNK cells.

\section{DISCUSSION}

A subset of non-classical NK cells $\left(\mathrm{CD} 56^{+} \mathrm{CD} 16^{\text {neg; }}\right.$; dNK cells) has become recognized for its role in vascular remodeling and tissue construction. Most knowledge of this angiogenic potential comes from reproductive biology, where these cells are undeniably important [5-8]. Relevance to cancer is evidenced by the ability of purified dNK cells to enhance growth of JEG3 choriocarcinoma cells when co-inoculated into immune deficient nude mice [5]. Examples of NK cells with a similar phenotype exist for cancer patients, including increased levels of $\mathrm{CD} 56^{+} \mathrm{CD} 16^{\mathrm{dim} / \mathrm{neg}}$ cells in tumor specimens from patients with breast cancer [2], non-small cell lung cancer (NSCLC) [3, 26], and colorectal cancer [27, 28]. Increased percentages of $\mathrm{CD} 56^{+} \mathrm{CD} 16^{\mathrm{dim} / \mathrm{neg}} \mathrm{NK}$ cells in the peripheral blood of some patients with these cancers suggest phenotype-altering effects can extend beyond the local tumor environment and may be indicative of disease progression and metastasis [2, 26-28]. Here we show that NK cells were altered within human RCC tumors compared with autologous peripheral blood samples. NK cells in the blood of RCC patients were poorly cytotoxic even though phenotypic alterations were less pronounced. Although not statistically significant in our small sample
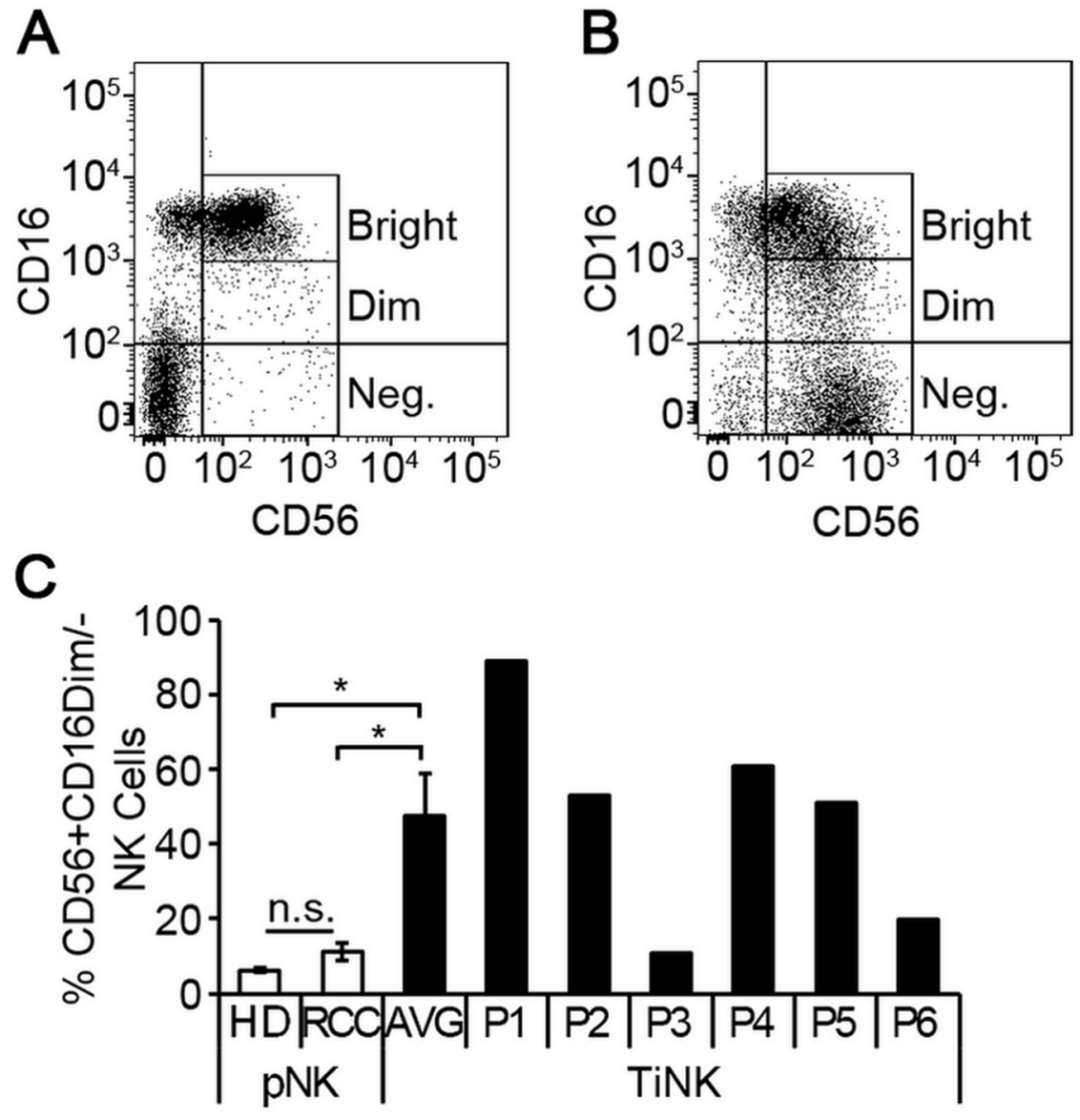

Figure 2: RCC tumor-infiltrated NK cells are phenotypically distinct from matched peripheral blood counterparts. NK cells were isolated from peripheral blood or resected tumor tissues of 6 RCC patients by negative selection and evaluated for expression of CD56 and CD16 by multi-color flow cytometry. Representative dot plots of NK cells isolated from peripheral blood (A) versus RCC tumor tissue (B) demonstrating CD56 and CD16 expression. (C) Percentage of CD56 $6^{+}$DD $16^{\text {dim/- }}$ NK cells for peripheral blood of healthy donors $(n=5)$ and RCC patients $(n=6)$, or RCC tumor-infiltrating NK cells (TiNK, $n=6)$ plotted as mean \pm SEM. Results for TiNK cells are also shown for each individual patient (P1 to P6). n.s., not significant; ${ }^{*} P \leq 0.05$ determined by Student's $t$-test. 
Table 2: Significant signaling pathways based on KEGG database

\begin{tabular}{llll}
\hline KEGG ID & Category & Genes in Pathway & $P$-value \\
\hline $\mathbf{0 4 0 6 6}$ & HIF1 signaling & HIF1 $\alpha$, VEGFA, FLT1, ANG1, ANG2, NFKB1, RELA, & $2.1 \mathrm{e}-8$ \\
& & BCL2, IL6 & \\
$\mathbf{0 4 6 6 8}$ & TNF signaling & TNF, NFkB1, IL1 $\beta$, RELA, CXCL1, CXCL3, CCL20, & $7.7 \mathrm{e}-7$ \\
& & IL6 & \\
$\mathbf{0 4 0 6 4}$ & NF kappa B signaling & NFKB1, NFKB2, TNF, RELA, CCL19, IL1 $\beta$, BCL2, & $2.0 \mathrm{e}-7$ \\
$\mathbf{0 5 2 0 2}$ & Misregulation in cancer & IL3, IL6, CCR7, RELA, IL1 $\beta$, NFKB1 & $1.4 \mathrm{e}-6$ \\
\hline
\end{tabular}

Abbreviations: KEGG, Kyoto encyclopedia of genes and genomes.

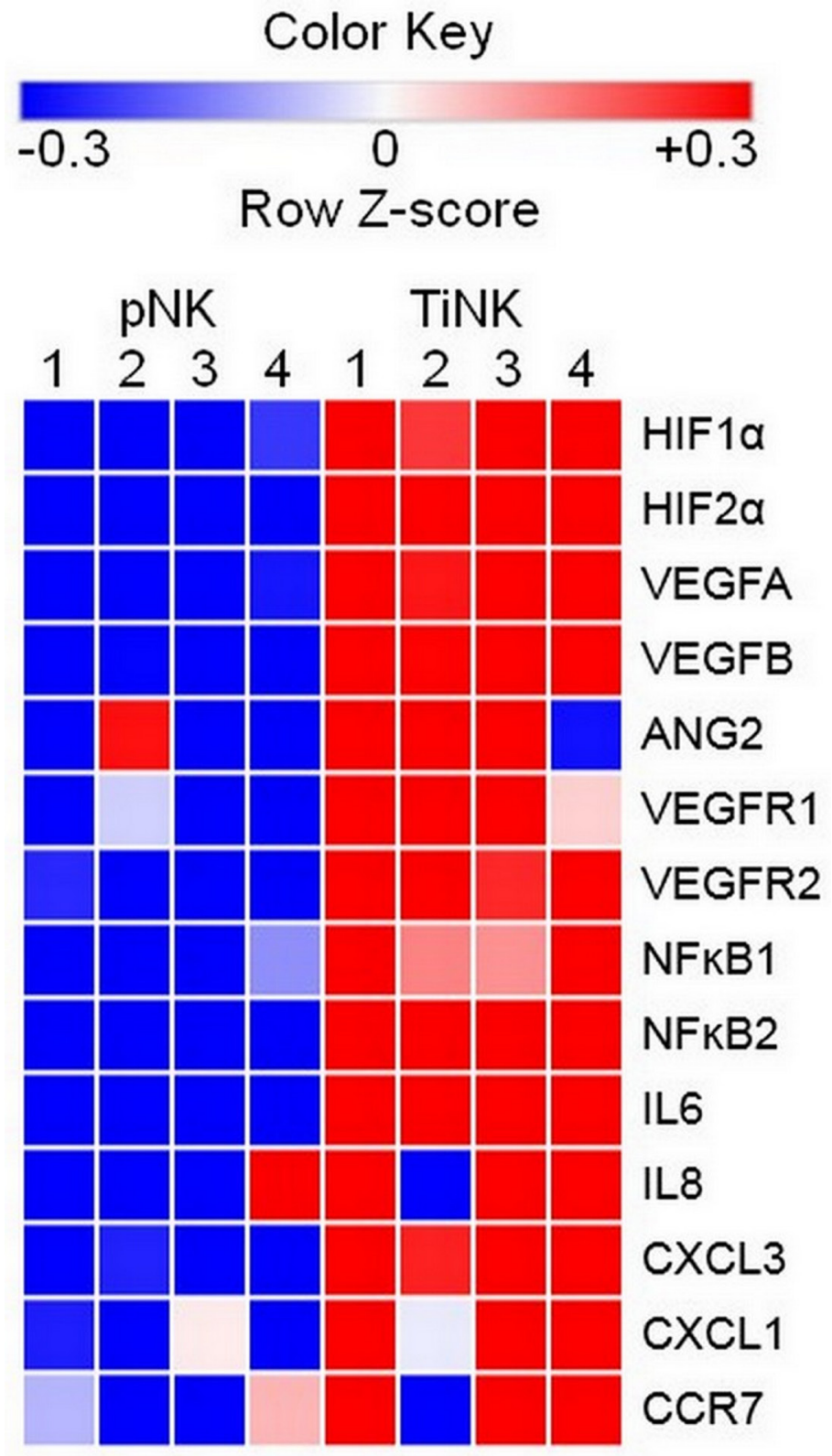

Figure 3: RCC TiNK cells have an altered transcriptional profiled compared to patient matched pNK cells. NK cells isolated from peripheral blood or RCC tumor tissues of 4 patients were isolated of total RNA and RT-qPCR analysis of the indicated targets performed in triplicate. Heat maps of transcriptional changes were developed for calculated Z-scores. Each row corresponds to the listed gene and columns to an individual patient (1-4) with source of NK cells peripheral blood (pNK) or RCC tumor (TiNK) indicated at the top. Scale bar with pseudocolors denotes differential gene expression: blue and red indicate low and high expression, respectively; white indicates no change in expression levels. 
size, these changes could reflect what occurs in the tumor. These data support a model in which $\mathrm{pNK}$ with the decidua-like phenotype are either directly recruited to RCC tumor sites or converted to phenotypically and functionally resemble dNK cells in the hypoxic tumor environment when encountering TGF $\beta$ to promote tumor establishment, growth and/or metastasis (Figure 5D).

TGF $\beta$ is highly expressed in the decidua in situ [29] and several studies have reported exposure of $\mathrm{pNK}$ cells from healthy donors to TGF $\beta$ mediated conversion to dNKlike cells $[30,31]$. TGF $\beta$ is also detected at high levels in various tumors and is the major immunosuppressive cytokine in the tumor microenvironment [32]. In RCC, TGF $\beta$ expression directly correlates with tumor stage and grade and is significantly elevated with metastatic disease $[33,34]$, suggesting its importance in tumor progression, immune evasion and potential role in transformation of TiNK cells $[4,35]$. Plasma TGF $\beta$ levels are upregulated in lung [36] and colon cancer patients [37]. The RCC patients studied here had 3-fold higher levels of TGF $\beta$ in the blood compared with healthy cancer-free volunteers. Circulating NK cells of RCC patients were phenotypical similar to healthy donors, but lacked full cytotoxic ability which we hypothesize is attributed to heightened levels of TGF $\beta$. A more pronounced diminution of cytotoxicity was observed for RCC TiNK cells which were predominantly dNK-like $\left(\mathrm{CD} 56^{+} \mathrm{CD} 16^{\mathrm{dim} / \mathrm{neg}}\right)$. TGF $\beta$ has been associated with NK cell dysfunction and changes in expression of activating and inhibitory receptors have been described in patients with breast cancer, melanoma, lung cancer and ovarian carcinoma [2-4, 35-38]. Many types of cells at the tumor site, including tumor cells, fibroblasts, stromal cells and infiltrating immune cells, express TGF $\beta$ to promote an immunosuppressive tumor microenvironment $[32,35]$. A recent report demonstrated that myeloidderived suppressor cells (MDSC) from patients with
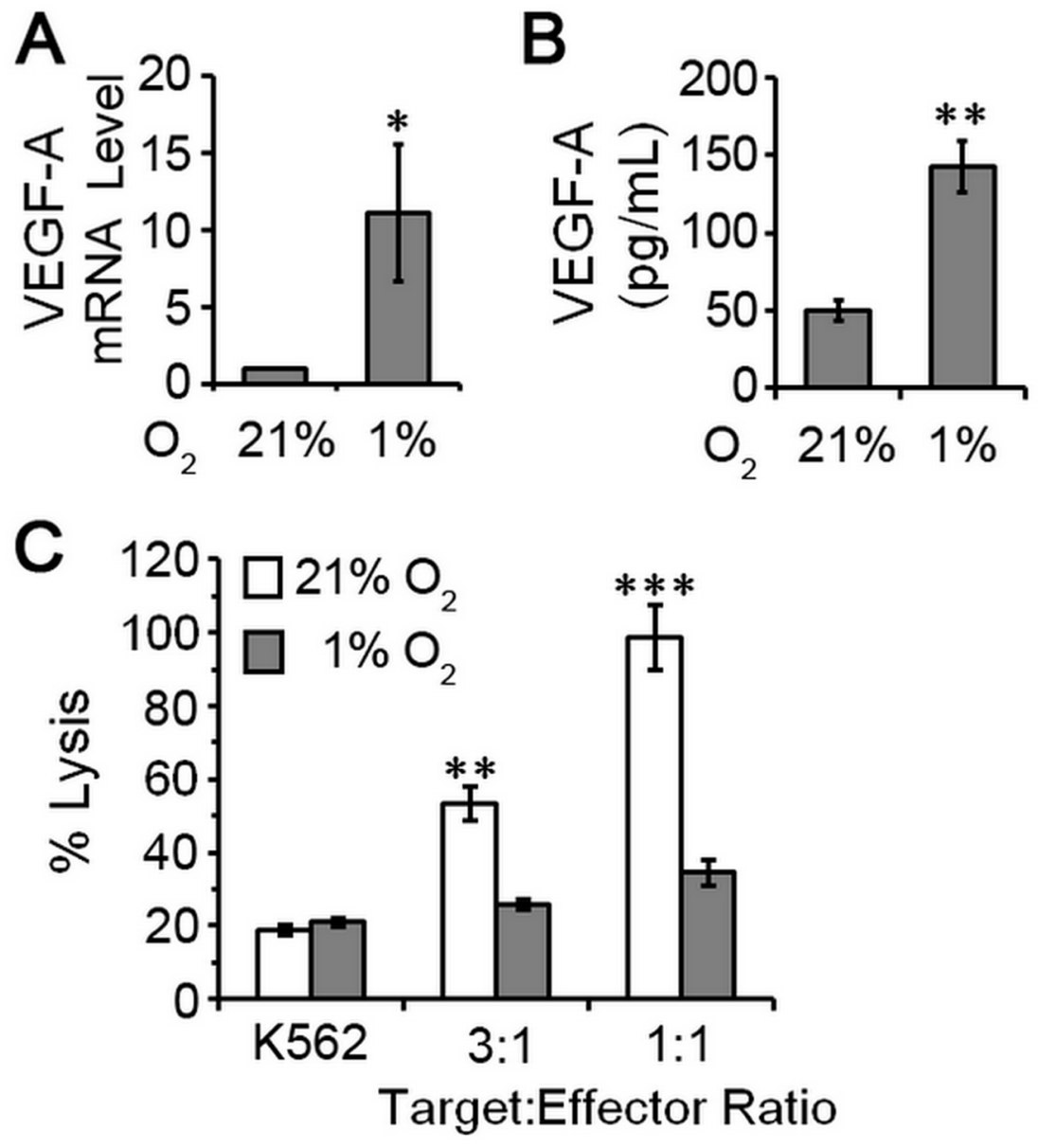

Figure 4: pNK cells exposed to hypoxia are poorly cytotoxic and proangiogenic. NK cells were isolated from peripheral blood of five healthy, cancer-free donors by negative selection and cultured under atmospheres consisting of $21 \% \mathrm{O}_{2}$ (normoxia) or $1 \% \mathrm{O}_{2}$ (hypoxia). (A) Relative levels of VEGF mRNA for NK cells cultured for 4 days. NK cells maintained under $21 \% \mathrm{O}_{2}$ conditions set to 1 for normalization and data plotted as mean \pm SEM ( $n=5$ donors). (B) VEGF secretion by pNK cells cultured under the indicated conditions quantified by ELISA of conditioned supernatants. Data plotted as mean $\pm \operatorname{SEM}(n=5$ donors). (C) Cytotoxic activity of pNK cells after 4 days of culture under the indicated oxygen conditions. Data are analyzed relative to K562 cells treated with digitonin serving as a positive control for cell death (set $=100 \%$ lysis) and plotted as mean $\pm \operatorname{SEM}\left(n=5\right.$ donors). ${ }^{*} P \leq 0.05 ;{ }^{* *} P \leq 0.01 ;{ }^{* * *} P \leq 0.001$ determined by oneway ANOVA with Newman-Keuls post-hoc analysis or paired Student's $t$-test. 
Table 3: Function of genes upregulated in $\mathrm{dNK}$ and TiNK cells

\begin{tabular}{|c|c|c|c|}
\hline Gene & Description & Function & Ref. \\
\hline VEGFA & Growth Factor & $\begin{array}{l}\text { Physiological/pathological angiogenesis; vascular permeability; } \\
\text { tumorigenesis }\end{array}$ & [62] \\
\hline VEGFB & Growth Factor & $\begin{array}{l}\text { Physiological/pathological angiogenesis; maintenance of blood } \\
\text { vessels }\end{array}$ & [63] \\
\hline ANG2 & Growth Factor & $\begin{array}{l}\text { Physiological/pathological angiogenesis; vascular permeability; } \\
\text { tumorigenesis }\end{array}$ & [64] \\
\hline IL6 & Cytokine & Acute and chronic inflammation; leukocyte recruitment & [65] \\
\hline IL8 & Cytokine & Acute and chronic inflammation; neutrophil recruitment & [66] \\
\hline CCL3 & Chemokine & Acute inflammation; leukocyte recruitment & {$[67]$} \\
\hline CXCL1 & Chemokine & Angiogenesis, inflammation, wound healing & [68] \\
\hline CCR7 & Receptor & Homing to lymphoid organs; recognizes CCL19 and CCL21 ligands & [69] \\
\hline CD146 & Receptor & NK cell adhesion; angiogenesis; immune response & [70] \\
\hline
\end{tabular}

advanced melanoma suppress NK cell activity through the production of TGF $\beta$ [39]. This would be in keeping with the immunomodulatory role of TGF $\beta$ in several tumors and tumor models [28, 32, 40], similar to what occurs for dNK cells [5, 29, 41]. Thus, TGF $\beta$, in combination with other factors and/or stimuli, such as hypoxia, may result in conversion of NK cells to an angiogenic phenotype within the decidua and tumor microenvironment. In support of this notion, inhibition of TGF $\beta$ has been reported to preserve function of activated and ex vivo expanded NK cells in tumor models [42].

A distinct feature of $\mathrm{RCC}$ is high numbers of tumor infiltrating lymphocytes. Consistent with previous reports [13-15], NK cells were present in the RCC tumors studied here, but percentages varied among patients and did not seem to correlate with pathologist-assigned staging criteria. RCC TiNK cells displayed the dNK-like phenotype and a distinct gene expression profile compared to peripheral blood counterparts. Among the upregulated genes, a number of genes within the HIF1 pathway were highly enriched, including the proangiogenic molecules, VEGFA, VEGFB, and ANG2. Thus, the NK cells isolated from the RCC tumors represented truly infiltrating populations and not peripheral blood contaminants through surrounding vasculature. Consistent with previous reports [22, 23], we demonstrated that hypoxia decreases NK cell cytotoxicity. Hypoxia also resulted in dramatic up-regulation of VEGF. Increased expression of VEGF in tumors and pathological angiogenesis is correlated with poor prognosis [43-45]. These findings confirm the association between phenotypic markers $\left(\mathrm{CD} 56^{+} \mathrm{CD} 16^{\mathrm{neg}}\right)$ and the ability to produce proangiogenic factors.

The presence of the RCC tumor appears to have a systemic effect on the cytotoxic activity of the pNK cell by augmenting circulating levels of TGF $\beta$. The observation that $\mathrm{CD} 56^{+} \mathrm{CD} 16^{+} \mathrm{NK}$ cells remain the dominate population in the peripheral blood of RCC patients suggests counter mechanisms are in play to retain surface markers, but these effects are less capable of preserving full cytotoxic function.
Our observations for RCC TiNK are consistent with findings that a $\mathrm{CD} 56^{+} \mathrm{CD} 16^{\text {neg }}$ subset of NK dominates in NSCLC tumors acting as proangiogenic cells by producing VEGF and PGF [26]. While other factors may contribute to the observed conversion of RCC TiNK cells, we have shown that TGF $\beta$ and hypoxia are two likely candidates. In support of this assertion, blocking TGF $\beta$ signaling can overcome immune suppression and enhance the effects of NK cell therapy $[46,47]$. As TGF $\beta$ is a pleotropic cytokine with important biological function, it is also intriguing to assume that proangiogenic function of RCC TiNK cells could be suppressed by targeted VEGF blocking agents including antibodies (i. e., bevacizumab) and tyrosine kinase inhibitors (TKIs), such as sunitinib and sorafenib. These medicines are already used clinically and could ameliorate or reverse tumor-supportive function of TiNK cells.

NK cell-mediated antitumor activity is commonly described and suggests these cells could be useful in therapeutic approaches. For RCC, rare patients with metastatic disease can experience spontaneous remission supporting the notion that RCC could be immunologically controlled [16, 17]. IL2, IL15, IL12, and IFN $\alpha$ (alpha interferon) have demonstrated some efficacy, with improved success noted when used in combination, however, response rates have been limited (ranging from 15-20\%) [11, 48-51]. The precise mechanisms by which these cytokines exert their antitumor effects are unknown, but it is believed activation and expansion of $\mathrm{T}$ cells and NK cells has a pivotal role [11, 12, 28, 42]. Of particular relevance to our studies are findings that IL12 has the ability to rescue NK cell antitumor activity by upregulation of CD16 [52]. As an alternative to cytokine stimulation of endogenous NK cells, other efforts have explored the benefit of NK cell infusion for RCC. Early studies tested tumor regressive properties of lymphokine activated CD3$\mathrm{CD}^{2} 6^{+}$cells (or LAKs) injected in combination with IL-2 $[53,54]$. Follow-up studies employed adoptive transfer of ex vivo activated allogeneic NK cells [55] and NK cell lines, such as NK-92 [56, 57]. NK cells have also been 
genetically modified to reduce expression of inhibitory receptors or augment production of cytokines or activating receptors. For example, NK cells engineered to express CXCR2 demonstrated improved trafficking and cytotoxic potential [58]. Chimeric antigen receptor (CAR) engineered NK-92 cells expressing a CAR specific to ErbB2 (Her2) or EGFR have shown efficacy in mouse models of human RCC [59, 60], which suggest opportunities for future benefit of CAR-NK cells in patients $[12,35,56]$.

Tumor-induced alterations of NK cells can limit tumor cell recognition and decrease their ability to interact with other immune cells. We showed that TGF $\beta$ and hypoxia are (at least) two factors capable of supporting the conversion of pNK cells to a dNK-like phenotype within RCC tumors. While these characteristics are conceivably beneficial for placentation, they may be exploited to support RCC growth and metastasis. Our findings that peripheral blood of RCC patients has higher levels of TGF $\beta$ and less cytotoxic NK cells suggests these parameters could be used to monitor disease progression. The utility of these criteria will require assessment of patients with early (stage I/II) versus advanced (stage III/ IV) disease, which is challenging in RCC as the majority of patients are in advanced stage at time of presentation.
The distinct gene expression signature of RCC TiNK cells discovered here provides additional targets responsible for proangiogenic differentiation of NK cells in the tumor environment. Improved knowledge of the extent and mechanisms of these newly-identified targets could permit development of strategies to restore the ability of NK cells to recognize and lyse tumors, particularly in patients with advanced disease. Along these lines, it is interesting to consider that combined use of TGF $\beta$ inhibitors and targeted VEGF blocking agents could ameliorate or reverse tumor-supportive function of TiNK cells. These and related studies in RCC and other cancer types may provide foundations for far reaching benefits in diseases in which inhibition or augmentation of vascular growth is warranted.

\section{MATERIALS AND METHODS}

\section{Human samples and processing}

Specimens from healthy donors (venous blood) and patients diagnosed with RCC (venous blood and tumor tissue) were prospectively collected with the donor's written informed consent in accordance with protocols approved by the Springfield Committee for Research

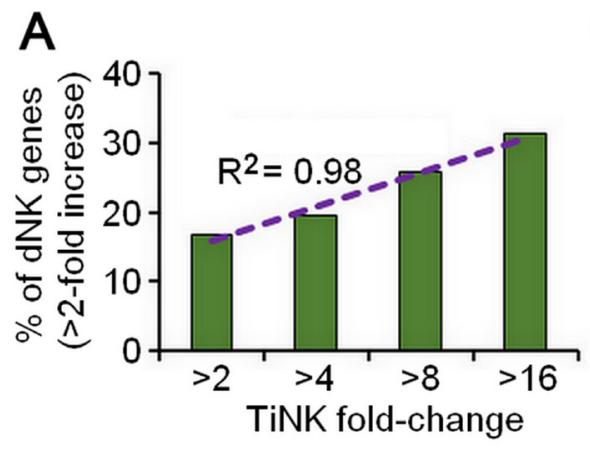

C

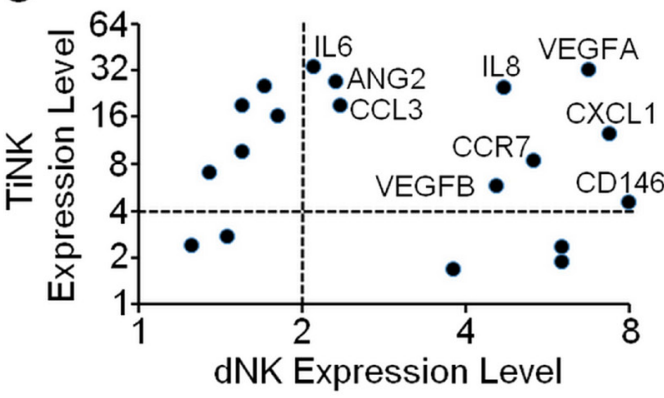

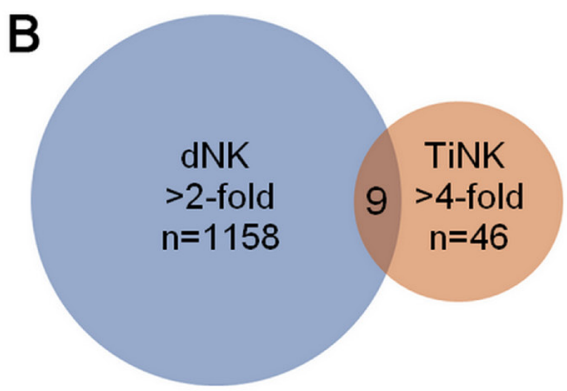

D

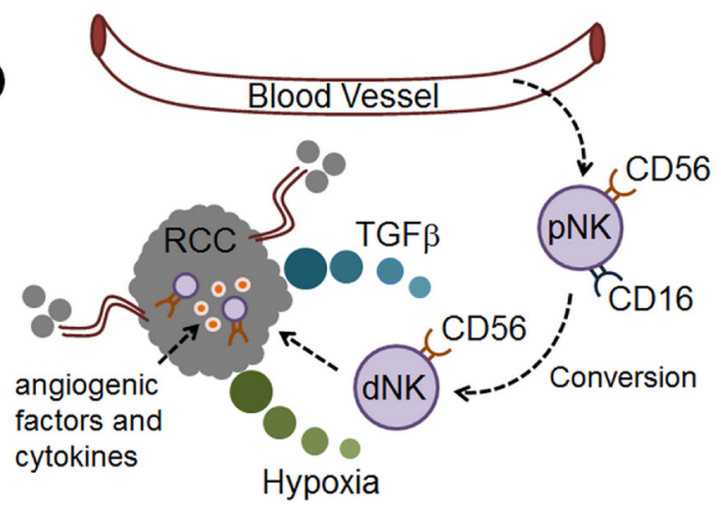

Figure 5: Similarities in gene expression for RCC TiNK and dNK cells. (A) Comparison of genes from a published microarray analysis for purified dNK cells [5] with any increase from the minimum hybridization threshold of 20 plotted against genes increased by 2-, 4-, 8-, or 16-fold by RT-qPCR analysis of TiNK cells with regression analysis. (B) Venn diagram of gene expression data for dNK cells (microarray data, $>2$-fold increase) versus RCC TiNK cells (RT-qPCR data, $>4$-fold increase). (C) Genes with any increase above the minimum hybridization threshold of 20 for dNK cells plotted against matched counterparts for TiNK cells with genes demonstrating $>2$-fold increase for $\mathrm{dNK}$ and $>4$-fold increase for RCC TiNK labeled. (D) Schematic diagram of potential role for CD56 $6^{+} \mathrm{CD} 16^{-/ \mathrm{dim}} \mathrm{dNK}$ like cells in RCC tumor development and metastasis. The noncytotoxic dNK-like cells are converted from pNK phenotype in the tumor environment when encountering low oxygen (hypoxia) and/or TGF $\beta$. This results in loss of cytotoxic function and production of angiogenic factors and cytokines supporting tumor growth and metastasis. 
Involving Human Subjects (SCRIHS) of Southern Illinois University School of Medicine. For RCC patients, morphological tumor characteristics were evaluated by a pathologist before release to the laboratory. All specimens lacked personal health information (de-identified) and were processed on the collection day.

Blood (10-20 mL) was diluted 1:2 with phosphate buffered saline (PBS), layered over Ficoll-Paque Plus (1.077 density, GE Healthcare, Uppsala, Sweden) and mononuclear cells separated by centrifugation at 300 ref for 30 minutes. RCC tumor tissues were minced and disrupted with a gentle MACS dissociator (program hTumor-01; Miltenyi Biotec, San Diego, CA, USA). Tissue fragments were incubated with RPMI 1640 medium supplemented with collagenase $(1 \mathrm{mg} / \mathrm{mL}$; Sigma-Aldrich, St. Louis, MO, USA), DNase I (100 $\mu \mathrm{g} /$ $\mathrm{mL}$; Roche NimbleGen Inc., Madison, WI, USA), 50 units $/ \mathrm{ml}$ each penicillin and streptomycin for 1 hour at $37^{\circ} \mathrm{C}$. The digested mixture was filtered through a $70-$ $\mu \mathrm{m}$ nylon cell strainer (BD Falcon, Franklin Lakes, NJ, USA) and cells collected by centrifugation at 500xg. Pelleted cells were suspended in 35\% Percoll solution (Sigma Aldrich, St. Louis, MO, USA) and centrifuged at 300 rcf for 30 minutes. Cells recovered from Ficoll or Percoll were washed twice with phosphate buffered saline (PBS). Viable cell counts were performed by trypan blue exclusion assay and cells were prepared for flow cytometry analysis or NK isolation as detailed below.

\section{NK cell isolation}

NK cells were isolated by negative selection (Dynabeads Untouched hNK Cell kit, Thermo Fisher Scientific, Grand Island, NY, USA) according to the manufacturer's instructions. The antibody-magnetic microbead cocktail removes T cells, B cells, NKT cells, dendritic cells, platelets, monocytes, granulocytes and erythroid cells to yield a population of NK cells that are bead- and antibody-free. The viability and purity of isolated NK cells was greater than $90 \%$ as determined by trypan blue exclusion assay and flow cytometry, respectively.

\section{NK cell phenotype by flow cytometry}

Purified NK cells were reacted with APCconjugated anti-CD45, PE-conjugated anti-CD3, Alexa 488-conjugated anti-CD56, and APCH7-conjugated antiCD16 in PBS supplemented with $0.5 \%$ BSA for 30 min on ice and washed three times. Viable cells were selected by gating on propidium iodide negative populations. NK cells were identified as the $\mathrm{CD} 45^{+} / \mathrm{CD} 3{ }^{-} / \mathrm{CD} 56^{+}$population and evaluated for expression of CD16. Cells left unstained or reacted with isotype control antibodies served as negative controls for gating. All antibodies were purchased from BD Biosciences (San Jose, CA, USA). Flow cytometry was performed on FACSAriaII (BD Biosciences) and analysis completed using FlowJo v10.0 software (FLOWJO, LLC, Ashland, OR, USA). Data are expressed as logarithmic values of fluorescence intensity.

\section{NK cell culture}

NK cells were cultured at $10^{6}$ cells $/ \mathrm{mL}$ in Myelocult medium (Stem Cell Technologies, Vancouver, BC, Canada) containing 10\% human serum, 5\% fetal calf serum, $20 \mathrm{ng} / \mathrm{mL}$ human interleukin-15 (hIL-15; PeproTech, Rocky Hill, NJ, USA), 20 ng/mL human stem cell factor (hSCF; PeproTech) and $10^{-6} \mathrm{M}$ hydrocortisone (Stem Cell Technologies, Vancouver, BC, Canada). Cells were cultured for four days under $21 \%$ or $1 \% \mathrm{O}_{2}$ in a humidified atmosphere at $37^{\circ} \mathrm{C}$.

\section{NK cell cytotoxic activity assays}

Human K562 erythroleukemia cells (CCL-243, ATCC, Manassas, VA, USA) were used to assay for NK activity. K562 cells were cultured in Iscove's Modified Dulbecco's Medium (IMDM; Mediatech Inc., Manassas, VA, USA) supplemented with 50 units $/ \mathrm{ml}$ each penicillin and streptomycin, and 10\% heat-inactivated fetal bovine serum (FBS) all from Hyclone Laboratories (Logan, UT, USA) at $37^{\circ} \mathrm{C}$ in a humidified $5 \% \mathrm{CO}_{2}$ atmosphere. Freshly isolated pNK cells (effectors) of healthy donors or RCC patients were evaluated for cytotoxic capacity using K562 (targets) and the Multi-Tox Fluor Cytoxicity Assay (Promega, Madison, WI, USA). K562 and NK cells were plated in triplicate into 96-well round bottom culture plates (BD Falcon, Franklin Lakes, NJ, USA) to achieve target:effector (T:E) ratios of $3: 1,1: 1$, and $1: 3$, respectively, in a total volume of $100 \mu \mathrm{L}$ of IMDM. Control wells containing only K562 or NK cells were included to measure spontaneous cell death whereas culture medium was assayed to control for background absorbance. K562 cells treated with the non-ionic detergent, Digitonin (Promega), at a final concentration of $30 \mu \mathrm{g} / \mathrm{mL}$ were included as positive controls for cell death. After 4 hours of incubation at $37^{\circ} \mathrm{C}$ in a humidified $5 \% \mathrm{CO}_{2}$ atmosphere, cells were reacted with bis-AAF-R110 substrate which is cleaved by the dead cell protease to release R110. The free R110 results in the formation of a yellow product that is quantitated by measuring fluorescence at $520 \mathrm{~nm}$ on a Glomax multimode plate reader (Promega). The amount of fluorescence is proportional to the number of lysed cells and percent cytotoxicity calculated using the equation: \% cytotoxicity $=[($ Experimental - Effector Spontaneous - Target Spontaneous)/(Target Maximum Target Spontaneous)] $\times 100$.

\section{Quantitative RT-PCR}

NK cells isolated from RCC patient blood or tumor tissue were extracted of total RNA using Ambion 
spin columns (Life Technologies, Carlsbad, CA, USA) with on-column DNase treatment (Promega). RNA was quantified by a Nanodrop 2000 (Life Technologies) and quality assessed by visualizing $18 \mathrm{~S}$ and $28 \mathrm{~S}$ ribosomal RNA bands separated through $1 \%$ agarose. RNA (100-300 ng) was reverse transcribed into cDNA using SuperScript VILO cDNA synthesis kit (Thermo Fisher Scientific, Waltham, MA, USA) and conditions: $25^{\circ} \mathrm{C}-10 \mathrm{~min}, 42^{\circ} \mathrm{C}-$ $60 \mathrm{~min}, 85^{\circ} \mathrm{C}-5 \mathrm{~min}$, and $4^{\circ} \mathrm{C}$-hold.

Differential gene expression was determined using cDNA (100 ng/reaction) as template and primer pairs for 79 genes selected from an in-house gene array. The details of this array including primer sequences and amplicon size have been described in detail [61]. For this study, interrogated genes included cytokines/chemokines/growth factors and their receptors; inflammation/activationassociated genes; single transduction/transcription factors; and cell lineage genes (Supplementary Table 2). Quantitative PCR reactions were performed in triplicate with iTaq Universal SYBR Green Supermix (Bio-Rad, Hercules, CA, USA) on a StepOne Plus thermocycler (Thermo Fisher Scientific-Applied Biosystems) using SYBR Green settings that included a final melt curve analysis; all reactions yielded a single peak. Changes in transcript levels were assessed by the $\Delta \Delta \mathrm{Ct}$ method and data normalized to $\beta$-actin. Paired $t$-test was used to identify genes with a fold change $\geq 5.0$ and a $P$-value $\leq 0.05$, and these genes were selected for the following analyses. Z-scores were calculated for each target gene using the equation $\mathrm{Z}=[($ target - mean $) /$ standard deviation $]$ and a heat map created using Morpheus software (Broad Institute, Cambridge, MA; https://software.broadinstitute. org/morpheus/). The Kyoto encyclopedia of gene and genomes (KEGG) pathway analysis was performed to predict the potential significant signaling pathways involved in conversion of pNK to TiNK $(p \leq 0.05)$.

\section{ELISA}

\section{TGF $\beta$}

TGF $\beta$ content in human serum was evaluated using a TGF $\beta$ ELISA Duoset (R\&D Systems) following the manufacturer's instructions. Briefly, to activate latent TGF $\beta$, plasma was incubated with $1 \mathrm{~N}$ hydrochloric acid $(\mathrm{HCl})$ followed by neutralization with $1.2 \mathrm{~N}$ sodium hydroxide $(\mathrm{NaOH}) / 0.5 \mathrm{M}$ 4-(2-hydroxyethyl)-1piperazineethanesulfonic acid (HEPES) buffer.

\section{VEGF}

NK cells were cultured under the indicated conditions for 4 days, and culture supernatants collected and stored at $-80^{\circ} \mathrm{C}$. VEGF concentration was measured using a VEGF Quantikine ELISA kit (R\&D Systems, Minneapolis, MN, USA) according to instructions. Results were normalized to viable cell counts determined at the time of collection.

\section{Statistical analysis}

Microsoft Excel or Prism 5 (GraphPad Software, Inc., La Jolla, CA, USA) was used to determine descriptive statistics (mean $\pm \mathrm{SD}$ or SEM) and calculate Z-scores. Significant differences between mean values were determined by paired or unpaired Student's $t$-test (twotailed) for independent groups or one-way ANOVA with Newman-Keuls post-hoc test for multiple comparisons where indicated. $P$-values are indicated by asterisks in the figures with level of significance reported as ${ }^{*} P \leq 0.05 ;{ }^{* *} P$ $\leq 0.01 ;{ }^{* * *} P \leq 0.001$.

\section{Abbreviations}

ANG: angiopoietin; CCL: C-C motif chemokine ligand; CCR: C-C motif chemokine receptor; $\mathrm{CD}$ : cluster of differentiation; CXCL: C-X-C motif chemokine ligand; CXCR: C-X-C motif chemokine receptor; dNK: decidua natural killer cells; FLT: fems-like tyrosine kinase; GM-CSF: granulocyte macrophage-colony stimulating factor; HIF: hypoxia inducible factor; IL: interleukin; INF $\alpha$ : alpha interferon; IFN $\gamma$ : gamma interferon; MDSC: myeloid-derived suppressor cells; PBMC: peripheral blood mononuclear cells; PGF: placenta growth factor; pNK: peripheral blood natural killer cells; NK: natural killer; NFкB: nuclear factor kappa B; RCC: renal cell carcinoma; TGF $\beta$ : transforming growth factor beta; TIL: tumor infiltrating lymphocytes; TiNK: tumor-infiltrated natural killer cells; TNF $\alpha$ : tumor necrosis factor alpha; VEGF: vascular endothelial growth factor.

\section{Author contributions}

Y.G. performed research, analyzed data and wrote the first draft of the manuscript. C.B.C., T.T., and H.H. performed research, analyzed data and edited the manuscript. K.R.D. analyzed data and edited the manuscript. K.R. consented patients and edited the manuscript. S.R.A., S.R., and D.S.T provided critical reagents, conceptual contributions, analyzed data and edited the manuscript. A.W. designed experiments, analyzed data, wrote the manuscript and was responsible for organization of the overall research effort. All authors read and approved the final manuscript.

\section{ACKNOWLEDGMENTS}

We thank the RCC patients for their participation in these studies and the Simmons Cancer Institute (SCI) Tissue Bank for procurement of specimens. We thank Dr. Andrea Braundmeier-Fleming (Department of Medical Microbiology, Immunology and Cell Biology, Southern Illinois University School of Medicine) and Dr. Peng Liu (Department of Medicine, University of North Carolina at Chapel Hill) for critical reading of the manuscript, and the 
flow cytometry laboratory of Melissa Roberts for expertise in cell sorting and analysis.

\section{CONFLICTS OF INTEREST}

The authors declare no conflicts of interest.

\section{FUNDING}

This work was supported by grants from the National Institute of Child Health and Human Development (R15HD073868; D.S.T.) and National Cancer Institute (R15CA173657; D.S.T. and A.W., R01CA199649; S.R.) and Simmons Cancer Institute (D.S.T., A.W., S.R.). The SIU School of Medicine flow cytometry equipment was supported by an award from the National Center for Research Resources (S10RR025674), and the Simmons Cancer Institute Tissue Bank supported in part by the Denim and Diamonds Research Fund. The funders had no role in study design, data collection, and analyses, preparation of the manuscript or decision to publish.

\section{REFERENCES}

1. Stabile H, Fionda C, Gismondi A, Santoni A. Role of distinct natural killer cell subsets in anticancer response. Front Immunol. 2017; 8:293. https://doi.org/10.3389/ fimmu.2017.00293. [PubMed]

2. Mamessier E, Sylvain A, Thibult ML, Houvenaeghel G, Jacquemier J, Castellano R, Goncalves A, André P, Romagné F, Thibault G, Viens P, Birnbaum D, Bertucci $\mathrm{F}$, et al. Human breast cancer cells enhance self tolerance by promoting evasion from NK cell antitumor immunity. $\mathrm{J}$ Clin Invest. 2011; 121:3609-3622. https://doi.org/10.1172/ JCI45816. [PubMed]

3. Carrega P, Morandi B, Costa R, Frumento G, Forte G, Altavilla G, Ratto GB, Mingari MC, Moretta L, Ferlazzo G. Natural killer cells infiltrating human nonsmall-cell lung cancer are enriched in CD56 bright CD16(-) cells and display an impaired capability to kill tumor cells. Cancer. 2008; 112:863-875. https://doi.org/10.1002/cncr.23239. [PubMed]

4. Bruno A, Ferlazzo G, Albini A, Noonan DM. A think tank of TINK/TANKs: tumor-infiltrating/tumor-associated natural killer cells in tumor progression and angiogenesis. J Natl Cancer Inst. 2014; 106:dju200. https://doi.org/10.1093/jnci/ dju200. [PubMed]

5. Hanna J, Goldman-Wohl D, Hamani Y, Avraham I, Greenfield C, Natanson-Yaron S, Prus D, Cohen-Daniel L, Arnon TI, Manaster I, Gazit R, Yutkin V, Benharroch D, et al. Decidual NK cells regulate key developmental processes at the human fetal-maternal interface. Nat Med. 2006; 12:1065-1074. https://doi.org/10.1038/nm1452. [PubMed]

6. Lash GE, Schiessl B, Kirkley M, Innes BA, Cooper A, Searle RF, Robson SC, Bulmer JN. Expression of angiogenic growth factors by uterine natural killer cells during early pregnancy. J Leukoc Biol. 2006; 80:572-580. https://doi.org/10.1189/jlb.0406250. [PubMed]

7. Zhang J, Chen Z, Smith GN, Croy BA. Natural killer celltriggered vascular transformation: maternal care before birth? Cell Mol Immunol. 2011; 8:1-11. https://doi. org/10.1038/cmi.2010.38. [PubMed]

8. Quenby S, Nik H, Innes B, Lash G, Turner M, Drury J, Bulmer J. Uterine natural killer cells and angiogenesis in recurrent reproductive failure. Hum Reprod. 2009; 24:4554. https://doi.org/10.1093/humrep/den348. [PubMed]

9. Onufrey V, Mohiuddin M. Radiation therapy in the treatment of metastatic renal cell carcinoma. Int J Radiat Oncol Biol Phys. 1985; 11:2007-2009. https://doi. org/10.1016/0360-3016(85)90285-8. [PubMed]

10. Yagoda A, Petrylak D, Thompson S. Cytotoxic chemotherapy for advanced renal cell carcinoma. Urol Clin North Am. 1993; 20:303-321. [PubMed]

11. Glaspy JA. Therapeutic options in the management of renal cell carcinoma. Semin Oncol. 2002; 29:41-46. https://doi. org/10.1053/sonc.2002.33083. [PubMed]

12. Murphy KA, James BR, Guan Y, Torry DS, Wilber A, Griffith TS. Exploiting natural anti-tumor immunity for metastatic renal cell carcinoma. Hum Vaccin Immunother. 2015; 11:1612-1620. https://doi.org/10.1080/21645515.2015.1035849. [PubMed]

13. Schleypen JS, Von Geldern M, Weiss EH, Kotzias N, Rohrmann K, Schendel DJ, Falk CS, Pohla H. Renal cell carcinoma-infiltrating natural killer cells express differential repertoires of activating and inhibitory receptors and are inhibited by specific HLA class I allotypes. Int J Cancer. 2003; 106:905-912. https://doi.org/10.1002/ijc.11321. [PubMed]

14. Prinz PU, Mendler AN, Brech D, Masouris I, Oberneder R, Noessner E. NK-cell dysfunction in human renal carcinoma reveals diacylglycerol kinase as key regulator and target for therapeutic intervention. Int J Cancer. 2014; 135:18321841. https://doi.org/10.1002/ijc.28837. [PubMed]

15. Xia Y, Zhang Q, Zhen Q, Zhao Y, Liu N, Ting L, Hao Y, Zhang $\mathrm{Y}$, Luo $\mathrm{C}, \mathrm{Wu} \mathrm{X}$. Negative regulation of tumorinfiltrating NK cell in clear cell renal cell carcinoma patients through the exosomal pathway. Oncotarget. 2017; 8:3778337795. https://doi.org/10.18632/oncotarget.16354. [PubMed]

16. Snow RM, Schellhammer PF. Spontaneous regression of metastatic renal cell carcinoma. Urology. 1982; 20:177-181. https://doi.org/10.1016/0090-4295(82)90356-9. [PubMed]

17. Edwards MJ, Anderson JA, Angel JR, Harty JI. Spontaneous regression of primary and metastatic renal cell carcinoma. J Urol. 1996; 155:1385. https://doi.org/10.1016/S00225347(01)66275-X. [PubMed]

18. Bellone G, Aste-Amezaga M, Trinchieri G, Rodeck U. Regulation of NK cell functions by TGF-beta 1. J Immunol. 1995; 155:1066-1073. [PubMed]

19. Harris AL. Hypoxia-a key regulatory factor in tumour growth. Nat Rev Cancer. 2002; 2:38-47. https://doi. org/10.1038/nrc704. [PubMed] 
20. Semenza GL. Defining the role of hypoxia-inducible factor 1 in cancer biology and therapeutics. Oncogene. 2010; 29:625-634. https://doi.org/10.1038/onc.2009.441. [PubMed]

21. Baginska J, Viry E, Paggetti J, Medves S, Berchem G, Moussay E, Janji B. The critical role of the tumor microenvironment in shaping natural killer cell-mediated anti-tumor immunity. Front Immunol. 2013; 4:490. https:// doi.org/10.3389/fimmu.2013.00490. [PubMed]

22. Fink T, Ebbesen P, Koppelhus U, Zachar V. Natural killer cell-mediated basal and interferon-enhanced cytotoxicity against liver cancer cells is significantly impaired under in vivo oxygen conditions. Scand J Immunol. 2003; 58:607612. https://doi.org/10.1111/j.1365-3083.2003.01347.x. [PubMed]

23. Sarkar S, Germeraad WT, Rouschop KM, Steeghs EM, van Gelder M, Bos GM, Wieten L. Hypoxia induced impairment of NK cell cytotoxicity against multiple myeloma can be overcome by IL-2 activation of the NK cells. PLoS One. 2013; 8:e64835. https://doi.org/10.1371/journal. pone.0064835. [PubMed]

24. Zhou Y, Fisher SJ, Janatpour M, Genbacev O, Dejana E, Wheelock M, Damsky CH. Human cytotrophoblasts adopt a vascular phenotype as they differentiate. A strategy for successful endovascular invasion. J Clin Invest. 1997; 99:2139-2151. https://doi.org/10.1172/JCI119387. [PubMed]

25. Zhou Y, Genbacev O, Damsky CH, Fisher SJ. Oxygen regulates human cytotrophoblast differentiation and invasion: implications for endovascular invasion in normal pregnancy and in pre-eclampsia. J Reprod Immunol. 1998; 39:197-213. https://doi.org/10.1016/S0165-0378(98)00022-9. [PubMed]

26. Bruno A, Focaccetti C, Pagani A, Imperatori AS, Spagnoletti M, Rotolo N, Cantelmo AR, Franzi F, Capella C, Ferlazzo G, Mortara L, Albini A, Noonan DM. The proangiogenic phenotype of natural killer cells in patients with non-small cell lung cancer. Neoplasia. 2013; 15:133-142. https://doi. org/10.1593/neo.121758. [PubMed]

27. Rocca YS, Roberti MP, Arriaga JM, Amat M, Bruno L, Pampena MB, Huertas E, Loria FS, Pairola A, Bianchini M, Mordoh J, Levy EM. Altered phenotype in peripheral blood and tumor-associated NK cells from colorectal cancer patients. Innate Immun. 2013; 19:76-85. https://doi. org/10.1177/1753425912453187. [PubMed]

28. Bruno A, Bassani B, Giuseppe D’Urso D, Pitaku I, Cassinotti E, Pelosi G, Boni L, Dominioni L, Noonan DM, Mortara L, Albini A. Angiogenin and the MMP9-TIMP2 axis are up-regulated in proangiogenic, decidual NK-like cells from patients with colorectal cancer. FASEB J. 2018; 32:53655377. https://doi.org/10.1096/fj.201701103R. [PubMed]

29. Jones RL, Stoikos C, Findlay JK, Salamonsen LA. TGFbeta superfamily expression and actions in the endometrium and placenta. Reproduction. 2006; 132:217-232. https://doi. org/10.1530/rep.1.01076. [PubMed]

30. Keskin DB, Allan DS, Rybalov B, Andzelm MM, Stern JN, Kopcow HD, Koopman LA, Strominger JL. TGFbeta promotes conversion of CD16+ peripheral blood NK cells into CD16- NK cells with similarities to decidual NK cells. Proc Natl Acad Sci U S A. 2007; 104:3378-3383. https:// doi.org/10.1073/pnas.0611098104. [PubMed]

31. Cerdeira AS, Rajakumar A, Royle CM, Lo A, Husain Z, Thadhani RI, Sukhatme VP, Karumanchi SA, Kopcow HD. Conversion of peripheral blood NK cells to a decidual NK-like phenotype by a cocktail of defined factors. J Immunol. 2013; 190:3939-3948. https://doi.org/10.4049/ jimmunol.1202582. [PubMed]

32. Bierie B, Moses HL. Tumor microenvironment: TGFbeta: The molecular Jekyll and hyde of cancer. Nat Rev Cancer. 2006; 6:506-520. https://doi.org/10.1038/nrc1926. [PubMed]

33. Hegele A, Varga Z, von Knobloch R, Heidenreich A, Kropf J, Hofmann R. TGF-beta1 in patients with renal cell carcinoma. Urol Res. 2002; 30:126-129. https://doi. org/10.1007/s00240-002-0245-6. [PubMed]

34. Mitropoulos D, Kiroudi A, Christelli E, Serafetinidis E, Zervas A, Anastasiou I, Dimopoulos C. Expression of transforming growth factor beta in renal cell carcinoma and matched non-involved renal tissue. Urol Res. 2004; 32:317322. https://doi.org/10.1007/s00240-003-0360-z. [PubMed]

35. Bassani B, Baci D, Gallazzi M, Poggi A, Bruno A, Mortara L. Natural killer cells as key players of tumor progression and angiogenesis: old and novel tools to divert their pro-tumor activities into potent anti-tumor effects. Cancers (Basel). 2019; 11:461. https://doi.org/10.3390/ cancers 11040461. [PubMed]

36. Kong FM, Washington MK, Jirtle RL, Anscher MS. Plasma transforming growth factor-beta 1 reflects disease status in patients with lung cancer after radiotherapy: a possible tumor marker. Lung Cancer. 1996; 16:47-59. https://doi. org/10.1016/S0169-5002(96)00611-3. [PubMed]

37. Narai S, Watanabe M, Hasegawa H, Nishibori H, Endo T, Kubota T, Kitajima M. Significance of transforming growth factor beta 1 as a new tumor marker for colorectal cancer. Int J Cancer. 2002; 97:508-511. https://doi.org/10.1002/ ijc.1631. [PubMed]

38. Lee JC, Lee KM, Kim DW, Heo DS. Elevated TGFbetal secretion and down-modulation of NKG2D underlies impaired NK cytotoxicity in cancer patients. J Immunol. 2004; 172:7335-7340. https://doi.org/10.4049/ jimmunol.172.12.7335. [PubMed]

39. Mao Y, Sarhan D, Steven A, Seliger B, Kiessling R, Lundqvist A. Inhibition of tumor-derived prostaglandin-e2 blocks the induction of myeloid-derived suppressor cells and recovers natural killer cell activity. Clin Cancer Res. 2014; 20:4096-4106. https://doi.org/10.1158/1078-0432. CCR-14-0635. [PubMed]

40. Yang L, Pang Y, Moses HL. TGF-beta and immune cells: an important regulatory axis in the tumor microenvironment and progression. Trends Immunol. 2010; 31:220-227. https://doi.org/10.1016/j.it.2010.04.002. [PubMed]

41. Carlino C, Stabile H, Morrone S, Bulla R, Soriani A, Agostinis C, Bossi F, Mocci C, Sarazani F, Tedesco F, 
Santoni A, Gismondi A. Recruitment of circulating NK cells through decidual tissues: a possible mechanism controlling NK cell accumulation in the uterus during early pregnancy. Blood. 2008; 111:3108-3115. https://doi.org/10.1182/ blood-2007-08-105965. [PubMed]

42. Otegbeye F, Ojo E, Moreton S, Mackowski N, Lee DA, de Lima M, Wald DN. Inhibiting TGF-beta signaling preserves the function of highly activated, in vitro expanded natural killer cells in AML and colon cancer models. PLoS One. 2018; 13:e0191358. https://doi.org/10.1371/journal. pone.0191358. [ [PubMed]

43. Bruno A, Pagani A, Pulze L, Albini A, Dallaglio K, Noonan DM, Mortara L. Orchestration of angiogenesis by immune cells. Front. Oncol. 2014; 4:131. https://doi.org/10.3389/ fonc.2014.00131. [PubMed]

44. Carmeliet P, Jain RK. Angiogenesis in cancer and other diseases. Nature. 2000; 407:249-257. https://doi. org/10.1038/35025220. [PubMed]

45. Yancopoulos GD, Davis S, Gale NW, Rudge JS, Wiegand SJ, Holash J. Vascular-specific growth factors and blood vessel formation. Nature. 2000; 407:242-248. https://doi. org/10.1038/35025215. [PubMed]

46. Wilson EB, El-Jawhari JJ, Neilson AL, Hall GD, Melcher AA, Meade JL, Cook GP. Human tumour immune evasion via TGF-beta blocks NK cell activation but not survival allowing therapeutic restoration of anti-tumour activity. PLoS One. 2011; 6:e22842. https://doi.org/10.1371/journal. pone.0022842. [PubMed]

47. Yang B, Liu H, Shi W, Wang Z, Sun S, Zhang G, Hu Y, Liu T, Jiao S. Blocking transforming growth factor-beta signaling pathway augments antitumor effect of adoptive NK-92 cell therapy. Int Immunopharmacol. 2013; 17:198-204. https://doi.org/10.1016/j.intimp.2013.06.003. [PubMed]

48. McDermott DF, Atkins MB. Immunotherapy of metastatic renal cell carcinoma. Cancer J. 2008; 14:320-324. https:// doi.org/10.1097/PPO.0b013e31818675c4. [PubMed]

49. Conlon KC, Lugli E, Welles HC, Rosenberg SA, Fojo AT, Morris JC, Fleisher TA, Dubois SP, Perera LP, Stewart DM, Goldman CK, Bryant BR, Decker JM, et al. Redistribution, hyperproliferation, activation of natural killer cells and CD8 T cells, and cytokine production during first-inhuman clinical trial of recombinant human interleukin-15 in patients with cancer. J. Clin. Oncol. 2015; 33:74-82. https:// doi.org/10.1200/JCO.2014.57.3329. [PubMed]

50. Gollob JA, Veenstra KG, Parker RA, Mier JW, McDermott DF, Clancy D, Tutin L, Koon H, Atkins MB. Phase I trial of concurrent twice-weekly recombinant human interleukin-12 plus low-dose IL-2 in patients with melanoma or renal cell carcinoma. J Clin Oncol. 2003; 21:2564-2573. https://doi. org/10.1200/JCO.2003.12.119. [PubMed]

51. Rosenberg SA, Yang JC, Topalian SL, Schwartzentruber DJ, Weber JS, Parkinson DR, Seipp CA, Einhorn JH, White DE. Treatment of 283 consecutive patients with metastatic melanoma or renal cell cancer using high-dose bolus interleukin 2. JAMA. 1994; 271:907-913. https://doi. org/10.1001/jama.1994.03510360033032. [PubMed]

52. Lehmann D, Spanholtz J, Sturtzel C, Tordoir M, Schlechta B, Groenewegen D, Hofer E. IL-12 directs maturation of ex vivo differentiated NK cells with improved therapeutic potential. PLoS One. 2014; 9:e87131. https://doi. org/10.1371/journal.pone.0087131. [PubMed]

53. Law TM, Motzer RJ, Mazumdar M, Sell KW, Walther PJ, O'Connell M, Khan A, Vlamis V, Vogelzang NJ, Bajorin DF. Phase III randomized trial of interleukin-2 with or without lymphokin- activated killer cells in the treatment of patients with advanced renal cell carcinoma. Cancer. 1995; 76:824-832. https://doi.org/10.1002/1097-0142(19950901)76:5<824::AIDCNCR2820760517>3.0.CO;2-N. [PubMed]

54. Rosenberg SA, Lotze MT, Muul LM, Leitman S, Chang AE, Ettinghausen SE, Matory YL, Skibber JM, Shiloni E, Vetto JT, Seipp CA, Simpson C, Reichert CM. Observations on the systemic administration of autologous lymphokine-activated killer cells and recombinant interleukin-2 to patients with metastatic cancer. N Engl J Med. 1985; 313:1485-1492. https://doi.org/10.1056/NEJM198512053132327. [PubMed]

55. Miller JS, Soignier Y, Panoskaltsis-Mortari A, McNearney SA, Yun GH, Fautsch SK, McKenna D, Le C, Defor TE, Burns LJ, Orchard PJ, Blazar BR, Wagner JE, et al. Successful adoptive transfer and in vivo expansion of human haploidentical NK cells in patients with cancer. Blood. 2005; 105:3051-3057. https://doi.org/10.1182/ blood-2004-07-2974. [PubMed]

56. Klingemann HG. Natural killer cell-based immunotherapeutic strategies. Cytotherapy. 2005; 7:16-22. https://doi.org/10.1016/S1465-3249(05)70785-4. [PubMed]

57. Tam YK, Mattinson JA, Doligosa K, Klingemann HG. Ex vivo expansion of highly cytotoxic human natural killer-92 cell line under current good manufacturing practice conditions for clinical adoptive cellular immunotherapy. Cytotherapy. 2003; 5:259-272. https://doi. org/10.1080/14653240310001523. [PubMed]

58. Kremer V, Ligtenberg MA, Zendehdel R, Seitz C, Duivenvoorden A, Wennerberg E, Colón E, SchermanPlogell AH, Lundqvist A. Genetic engineering of human NK cells to express CXCR2 improves migration to renal cell carcinoma. J Immunother Cancer. 2017; 5:73. https:// doi.org/10.1186/s40425-017-0275-9. [PubMed]

59. Schönfeld K, Sahm C, Zhang C, Naundorf S, Brendel C, Odendahl M, Nowakowska P, Bönig H, Köhl U, Kloess S, Köhler S, Holtgreve-Grez H, Jauch A, et al. Selective Inhibition of Tumor Growth by Clonal NK Cells Expressing an ErbB2/HER2-Specific Chimeric Antigen Receptor. Mol Ther. 2015; 23:330-338. https://doi.org/10.1038/ mt.2014.219. [PubMed]

60. Zhang Q, Tian K, Xu J, Zhang H, Li L, Fu Q, Chai D, Li H, Zheng J. Synergistic Effects of Cabozantinib and EGFRSpecific CAR-NK-92 Cells in Renal Cell Carcinoma. J Immunol Res. 2017; 2017:6915912. https://doi. org/10.1155/2017/6915912. [PubMed] 
61. Volk-Draper LD, Hall KL, Wilber AC, Ran S. Lymphatic endothelial progenitors originate from plastic myeloid cells activated by toll-like receptor-4. PLoS One. 2017; 12:e017957. https://doi.org/10.1371/journal.pone.0179257. [PubMed]

62. Nicol D, Hii SI, Walsh M, Teh B, Thompson L, Kennett C, Gotley D. Vascular endothelial growth factor expression is increased in renal cell carcinoma. J Urol. 1997; 157:14821486. https://doi.org/10.1016/S0022-5347(01)65028-6. [PubMed]

63. Yang X, Zhang Y, Hosaka K, Andersson P, Wang J, Tholander F, Cao Z, Morikawa H, Tegnér J, Yang Y, Iwamoto $\mathrm{H}$, Lim S, Cao Y. VEGF-B promotes cancer metastasis through a VEGF-A-indepenent mechanism and serves as a marker of poor prognosis for cancer patients. Proc Natl Acad Sci U S A. 2015; 112:E2900-E2909. https:// doi.org/10.1073/pnas.1503500112. [PubMed]

64. Mazzieri R, Pucci F, Moi D, Zonari E, Ranghetti A, Berti A, Politi LS, Gentner B, Brown JL, Naldini L, De Palma M. Targeting the ANG2/TIE2 axis inhibits tumor growth and metastasis by impairing angiogenesis and disabling rebounds of proangiogenic myeloid cells. Cancer Cell. 2011; 19:512-526. https://doi.org/10.1016/j. ccr.2011.02.005. [PubMed]

65. Gopinathan G, Milagre C, Pearce OM, Reynolds LE, Hodivala-Dilke K, Leinster DA, Zhong H, Hollingsworth RE, Thompson R, Whiteford JR, Balkwill F. Interleukin-6 stimulates defective angiogenesis. Cancer Res. 2015; 75:3098-3107. https://doi.org/10.1158/0008-5472.CAN15-1227. [PubMed]
66. Lee YS, Choi I, Ning Y, Kim NY, Khatchadourian V, Yang D, Chung HK, Choi D, LaBonte MJ, Ladner RD, Nagulapalli Venkata KC, Rosenberg DO, Petasis $\mathrm{NA}$, et al. Interleukin- 8 and its receptor CXCR2 in the tumour microenvironment promote colon cancer growth, progression and metastasis. Br J Cancer. 2012; 106:18331841. https://doi.org/10.1038/bjc.2012.177. [PubMed]

67. Liao YY, Tsai HC, Chou PY, Wang SW, Chen HT, Lin YM, Chiang IP, Chang TM, Hsu SK, Chou MC, Tang CH, Fong YC. CCL3 promotes angiogenesis by dyregulation of miR-374b/VEGF-A axis in human osteosarcoma cells. Oncotarget. 2016; 7:4310-4325. https://doi.org/10.18632/ oncotarget.6708. [PubMed]

68. Wei ZW, Xia GK, Wu Y, Chen W, Xiang Z, Schwartz RE, Brekken RA, Awasthi N, He YL, Zhang CH. CXCL1 promotes tumor growth through VEGF pathway activation and is associated with inferior survival in gastric cancer. Cancer Lett. 2015; 359:335-343. https://doi.org/10.1016/j. canlet.2015.01.033. [PubMed]

69. Li Y, Qui X, Zhang S, Zhang Q, Wang E. Hypoxia induced CCR7 expression via HIF-1alpha and HIF-2alpha correlates with migration and invasion of lung cancer cells. Cancer Biol Ther. 2009; 8:322-330. https://doi.org/10.4161/ cbt.8.4.7332. [PubMed]

70. Yan X, Lin Y, Yang D, Shen Y, Yuan M, Zhang Z, Li P, Xia H, Li L, Luo D, Liu Q, Mann K, Bader BL. A novel antiCD146 monoclonal antibody, AA98, inhibits angiogenesis and tumor growth. Blood. 2003; 102:184-191. https://doi. org/10.1182/blood-2002-04-1004. [PubMed] 